\title{
THE EFFECT OF HEALTH SERVICE QUALITY BY USING SERVICE QUALITY DIMENSION ON THE CUSTOMER SATISFACTION AT BALONGSARI HEALTH CENTER
}

\author{
Putri Kholifatul Wanda*, Windijarto, Suaedi Falih \\ Postgraduate School, University of Airlangga, Surabaya, Indonesia \\ ${ }^{*}$ E-mail: kwanda1807@gmail.com
}

\begin{abstract}
One of the indicators to measure the quality of health service is by observing customer satisfaction. Besides that, it could be used as a standard for a health center. The result of satisfaction level measurement leads to the dimension, characteristics, and indicators which make the patient feel satisfied or not towards the service by the health center officer. Thus, the health center officer could know and progress or improve if there is a service that is not satisfying according to the patient's point of view and maintain the good service. This study aims to obtain an overview of customer satisfaction level by using five dimensions of service quality, which are tangible, reliability, responsiveness, assurance, and empathy. This study was explanatory research with quantitative approach. The data sample was 73 by using a random sampling method. The data analysis used univariate descriptive analysis. Importance-performance test and the Cartesian diagram were used to observe the level of conformity between the expectation and reality of service quality. The result of the descriptive analysis showed that the satisfaction level of the customer based on the average dimension was very satisfied. The result of the importance-performance test showed that the assurance dimension should be improved, which was the skill of the officer on doing the job and empathy dimension which was the doctor should know the patient who comes to get treatment.
\end{abstract}

\section{KEY WORDS}

Service quality, importance-performance analysis, health service quality, patient satisfaction, public service.

A good health service is one of the points which help in building health because the healthy society will lead to good human resource quality. Based on Constitution No.25 year 2000 about national development program year 2000-2004. It mentioned that the main aim of health means program is successful management of health service and affordable for everyone. The aim of that program is the availability of basic health service organized by Health Center "Puskesmas" and a reference (follow up at a hospital) for state or private hospital supported by the society. It is already regulated in Permenkes No. 75 year 2014 about performing health service so that all the officers could do the service based on the determined standards. There are some health center accreditation based on Permenkes No. 46 year 2015, which are unaccredited, basic accredited, middle accredited, good accredited, and excellent accredited. Surabaya city has 63 health centers in total, but not all of them has an accreditation.

From 35 health centers, there are only two health centers with excellent accreditation, which are Balongsari Health Center and Sememi Health Center. To increase their health service, The Health ministry gives awards to the health center that has more dedication to the health field each year. From several health centers in Surabaya city, Balongsari Health Center got the second rank as Achieving First Level Health Facility nationally in 2016 in the category of excellent accreditation. This achievement made Surabaya city proud, especially Balongsari Health Center. This achievement could encourage the other health centers in Surabaya city to improve their health service. By using the ServQual Method, it is expected to know the effect of health service quality towards the customer satisfaction in Balongsari Health Center to obtain a good achievement. 
Table 1 - The List of Health Center Accreditation in Surabaya

\begin{tabular}{|c|c|c|}
\hline No & Health Center Name & Accreditation Status \\
\hline 1 & Sememi Health Center & EXCELLENT \\
\hline 2 & Gayungan Health Center & BASIC \\
\hline 3 & Tambak Rejo Health Center & MIDDLE \\
\hline 4 & Balongsari Health Center & EXCELLENT \\
\hline 5 & Simomulyo Health Center & GOOD \\
\hline 6 & Sawahan Health Center & MIDDLE \\
\hline 7 & Tanah Kali Kedinding Health Center & MIDDLE \\
\hline 8 & Jagir Health Center & MIDDLE \\
\hline 9 & Dupak Health Center & GOOD \\
\hline 10 & Pucang Sewu Health Center & GOOD \\
\hline 11 & Gunung Anyar Health Center & GOOD \\
\hline 12 & Medokan Ayu Health Center & GOOD \\
\hline 13 & Keputih Health Center & GOOD \\
\hline 14 & Manukan Kulon Health Center & GOOD \\
\hline 15 & Gading Health Center & MIDDLE \\
\hline 16 & Ketabang Health Center & MIDDLE \\
\hline 17 & Krembangan Selatan Health Center & GOOD \\
\hline 18 & Kenjeran Health Center & MIDDLE \\
\hline 19 & Klampis Ngasem Health Center & MIDDLE \\
\hline 20 & Kalijudan Health Center & GOOD \\
\hline 21 & Wiyung Health Center & MIDDLE \\
\hline 22 & Benowo Health Center & MIDDLE \\
\hline 23 & Bulak Banteng Health Center & MIDDLE \\
\hline 24 & Kebonsari Health Center & MIDDLE \\
\hline 25 & Pegirian Health Center & GOOD \\
\hline 26 & Tambakrejo Health Center & MIDDLE \\
\hline 27 & Jeruk Health Center & GOOD \\
\hline 28 & Tenggilis Health Center & MIDDLE \\
\hline 29 & Gayungan Health Center & BASIC \\
\hline 30 & Tanjungsari Health Center & MIDDLE \\
\hline 31 & Simomulyo Health Center & GOOD \\
\hline 32 & Putat Jaya Health Center & MIDDLE \\
\hline 33 & Tanah Kalikedinding Health Center & MIDDLE \\
\hline 34 & Dupak Health Center & GOOD \\
\hline 35 & Pegirian Health Center & GOOD \\
\hline
\end{tabular}

Source: website dinkes.surabaya.go.id Data, processed.

\section{METHODS OF RESEARCH}

This study used questionnaires distributed directly to the respondents. It used a simple random sampling, which was a technique that gives the same chance to each part of the population to be selected as a sample (Sugiyono, 2009:122). The sample in this study were 73 respondents and they were outpatient of Balongsari Health Center. The basic concepts used in this study were five dimensions of SERVQUAL from Parasuraman et al. in Tjiptono (2007), namely Tangible, Reliability, Responsiveness, Assurance, and Empathy. The data analysis techniques were Descriptive Analysis, Importance-Performance Analysis, and Cartesius Diagram.

\section{RESULTS OF STUDY}

A validity test was performed to observe the respondents' answer level so that the study instrument measurement could be done precisely. This study involved 73 respondents with an $R$ table value of 0.227 . The study data showed that each question on every variable stated as valid if the $R$ calculate is bigger than the $R$ table. The result was shown in Table 2. The reliability is an index that shows consistency and stability of result value from a measurement. A study instrument is stated as reliable if the instrument is consistent on giving the rating on what it is measured. The result of reliability test on every variable on the 
service quality; tangible, reliability, responsiveness, assurance, dan empathy, was shown in Table 3.

Table 2 - Validity Test

\begin{tabular}{|c|c|c|c|c|}
\hline \multirow[b]{2}{*}{ No } & \multirow{2}{*}{ R Table } & \multicolumn{2}{|c|}{ R Calculate } & \multirow[b]{2}{*}{ Validity Tes } \\
\hline & & Expectation & Reality & \\
\hline \multicolumn{5}{|c|}{ Tangible Variable (X1) } \\
\hline 1 & 0.227 & 0.851 & 0.886 & Valid \\
\hline 2 & 0.227 & 0.914 & 0.952 & Valid \\
\hline 3 & 0.227 & 0.888 & 0.932 & Valid \\
\hline 4 & 0.227 & 0.817 & 0.944 & Valid \\
\hline 5 & 0.227 & 0.764 & 0.912 & Valid \\
\hline \multicolumn{5}{|c|}{ Reliability Variable (X2) } \\
\hline 1 & 0.227 & 0.861 & 0.887 & Valid \\
\hline 2 & 0.227 & 0.823 & 0.899 & Valid \\
\hline 3 & 0.227 & 0890 & 0.893 & Valid \\
\hline 4 & 0.227 & 0.765 & 0.842 & Valid \\
\hline 5 & 0.227 & 0.868 & 0.894 & Valid \\
\hline 6 & 0.227 & 0.747 & 0.869 & Valid \\
\hline \multicolumn{5}{|c|}{ Responsiveness Variable (X3) } \\
\hline 1 & 0.227 & 0.778 & 0.795 & Valid \\
\hline 2 & 0.227 & 0.859 & 0.922 & Valid \\
\hline 3 & 0.227 & 0.833 & 0.859 & Valid \\
\hline 4 & 0.227 & 0.850 & 0.876 & Valid \\
\hline 5 & 0.227 & 0.847 & 0.894 & Valid \\
\hline \multicolumn{5}{|c|}{ Assurance Variable $(\mathrm{X} 4)$} \\
\hline 1 & 0.227 & 0.835 & 0.884 & Valid \\
\hline 2 & 0.227 & 0.789 & 0.856 & Valid \\
\hline 3 & 0.227 & 0.876 & 0.854 & Valid \\
\hline 4 & 0.227 & 0.916 & 0.901 & Valid \\
\hline 5 & 0.227 & 0.799 & 0.848 & Valid \\
\hline \multicolumn{5}{|c|}{ Empathy Variable (X5) } \\
\hline 1 & 0.227 & 0.817 & 0.856 & Valid \\
\hline 2 & 0.227 & 0.874 & 0.905 & Valid \\
\hline 3 & 0.227 & 0.733 & 0.824 & Valid \\
\hline 4 & 0.227 & 0.811 & 0.876 & Valid \\
\hline 5 & 0.227 & 0.840 & 0.907 & Valid \\
\hline 6 & 0.227 & 0.907 & 0.889 & Valid \\
\hline 7 & 0.227 & 0.725 & 0.856 & Valid \\
\hline
\end{tabular}

Table 3 - Reliability Test

\begin{tabular}{|l|c|c|c|}
\hline \multirow{2}{*}{ Variable } & \multicolumn{2}{|c|}{$\begin{array}{c}\text { Coefficient of Alpha } \\
\text { Cronbach's }\end{array}$} & \multirow{2}{*}{ Result } \\
\cline { 2 - 3 } & Expectation & Reality & \\
\hline Tangible (X1) & 0.904 & 0.957 & Reliable \\
\hline Reliability (X2) & 0.903 & 0.941 & Reliable \\
\hline Responsiveness (X3) & 0.888 & 0.918 & Reliable \\
\hline Assurance (X4) & 0.897 & 0.918 & Reliable \\
\hline Empathy (X5) & 0.915 & 0.948 & Reliable \\
\hline
\end{tabular}

The reliability item was tested to observe the alpha coefficient value whether it is bigger or smaller than the $\mathrm{R}$ table by using reliability analysis. Table 3 showed that the Tangible variable (X1) was reliable with expectation and reality alpha coefficient of 0.904 and 0.957 , respectively. The Reliability variable $(\mathrm{X} 2)$ was reliable with expectation and reality alpha coefficient of 0.903 and 0.941 , respectively. The Responsiveness variable (X3) was reliable with expectation and reality alpha coefficient of 0.888 and 0.918 , respectively. The Assurance variable (X4) was reliable with expectation and reality alpha coefficient of 0.897 and 0.918 , respectively. The Empathy variable (X5) was reliable with expectation and reality 
alpha coefficient of 0.915 and 0.948 , respectively. It is concluded that all the results were reliable.

The variable of service quality was measured in five dimensions, which are tangible, reliability, responsiveness, assurance, and empathy. The result of suitability average between expectation and reality of dimension of service quality altogether.

Table 4 - Suitability of Expectation and Reality

\begin{tabular}{|l|c|c|c|c|c|}
\hline \multicolumn{1}{|c|}{ Item } & Expectation & Reality & $\mathrm{X}$ & $\mathrm{Y}$ & Suitability (\%) \\
\hline Tangible & 766 & 679 & 9,30 & 10.49 & 88,65 \\
\hline Reliability & 959 & 857 & 11,73 & 13,13 & 89,33 \\
\hline Responsiveness & 787 & 687 & 9,41 & 10,78 & 87,29 \\
\hline Assurance & 794 & 708 & 9,69 & 10,87 & 89,14 \\
\hline Empathy & 1172 & 1012 & 13,86 & 16,05 & 86,35 \\
\hline \multicolumn{1}{|c|}{ Item } & $y$ & $x$ & $(x)$ & $(y)$ & $(x)$ \\
\hline \multicolumn{2}{|c|}{} & & 10,79 & 14,36 & 75,13 \\
\hline
\end{tabular}

The average of expectation value $(y)$ and reality value $(x)$ on Table 3 was used for determining the quadrant position on Cartesian diagram in Figure 1.

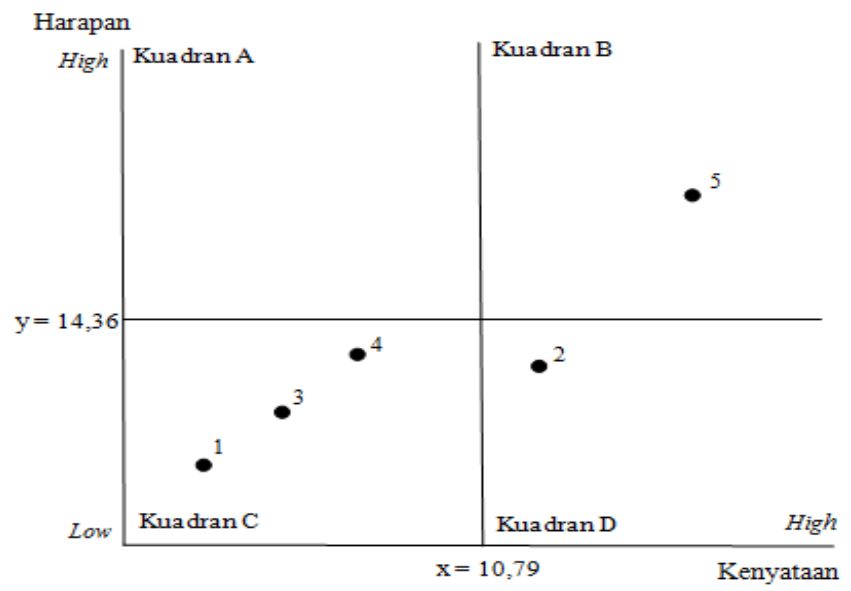

Figure 1 - Cartesian Diagram of Service Quality Variables

\section{DISCUSSION OF RESULTS}

Ovreveit in Sundari (2014) stated that quality in health service consists of consumer quality (related to whether the service fits the patient's desire or not), professional quality (related to whether the service could fulfill the patient's need as diagnosed by the professional), and management quality (related to the service that is given without waste and mistakes, affordable, and met the official and other regulations).

One of the main elements in measuring the service through customer satisfaction is customer feeling that is happy or disappointed originated from the ratio between the result (impression) from a product and their expectation (Kotler, 1997:36). To measure the ratio between expectation and reality, the service could be done by using importance-performance analysis or the analysis of customer satisfaction and the work of service officer to obtain suitability level between expectation and reality of service quality (Supranto, 2004 in Suhardi, 2009). The customer satisfaction was also determined by the service quality from five dimensions of the gap, which is the discrepancy of perceived service and expected service. If it is positive, then the service quality fits the expectation and on the contrary, if it is negative, the service quality does not fit the expectation.

Table 3 showed that the suitability between expectation and reality of service quality variable from five dimensions had high suitability above $80 \%$. The highest percentage of suitability was $89.33 \%$, reliability variable and the lowest percentage of suitability was 
$86.35 \%$, empathy variable. The total suitability of service quality was in the middle category, which was $75.13 \%$. It was obtained from the average of five dimensions of service quality variables.

Figure 1 showed the Cartesian diagram based on the placement of service quality variables and grouped based on the average of expectation and reality value. It was positioned in the diagram in one of four quadrants. There was no health service quality found at Quadrant A in this study. There was one variable found in Quadrat B, which was empathy variable and one in Quadrant $D$, which was reliability. Most of the variables were in Quadrant $\mathrm{C}$, which were tangible, responsiveness, and assurance.

The result of importance-performance analysis showed that there was suitability between the expectation and reality of service quality variables altogether with an average percentage of 75.13 , that belongs to middle suitability. Thus, the Balongsari Health Center was satisfying enough.

\section{CONCLUSION}

Based on the study conducted by using questionnaire with 73 respondents, it concluded that the suitability between the expectation and reality of health service quality in Balongsari Health Center in Surabaya were tangible $(88.65 \%)$, reliability $(89.33 \%)$, responsiveness(87.29\%), Assurance $(89.14 \%)$, and empathy $(86.35 \%)$. There was no service quality variable found on Quadrant A. Empathy variable was on Quadrant B, Reliability variable was on Quadrant D, and the rest of the variables were on Quadrant C.

\section{REFERENCES}

1. Kotler, Philip. 2007. Manajemen Pemasaran, Analisis Perencanaan, Pengendalian. Prentice Hall, Edisi Bahasa Indonesia, Jakarta: Salemba Empat.

2. Peraturan Menteri Kesehatan Nomor 75 tahun 2014 tentang Pusat Kesehatan Masyarakat.

3. Peraturan Menteri Kesehatan Nomor 46 tahun 2015 tentang Akreditasi Puskesmas, Klinik Pratama, Tempat Praktik Mandiri Dokter, dan Tempat Praktik Mandiri Dokter Gigi.

4. Sugiyono. 2009. Metode Penelitian Kuantitatif Kualitatif R \& D. Bandung: Alfabeta.

5. Sugiyono, 2008. Metode Penelitian Administrasi. Bandung: Alfabeta.

6. Suhardi. 2009. Analisis Kesesuaian Antara Harapan dan Kenyataan Mutu Pelayanan Yang Diterima Di Unit Rawat Inap RSUD Dr.Soedjati Soemodiardjo Kabupaten Grobogan. Thesis Universitas Diponegoro.

7. Sundari, Made N.P. 2014. Kualitas Pelayanan Kesehatan di RSUP Sanglah Denpasar dari Prespektif Pelanggan Internal dan Eksternal. Thesis Universitas Udayana.

8. Tjiptono, Fandy. 2007. Strategi Pemasaran. Edisi ke dua. Yogyakarta: penerbit Andi.

9. Tjiptono, Fandy. 2006. Manajemen Pelayanan Jasa. Yogyakarta: Penerbit Andi.

10. Tjiptono, Fandy. 2005. Service Quality and Satisfaction. Edisi 2. Andi, Yogyakarta.

11. Tjiptono, Fandy. 2002. Manajemen Jasa. Cetakan II. Yogyakarta: Andi Offset.

12. Tjiptono, Fandy. 1997. Srategi Pemasaran . Yogyakarta: Andi. 